Article

\title{
Challenges and Strategies in Place-Based Multi-Stakeholder Collaboration for Sustainability: Learning from Experiences in the Global South
}

\author{
Bárbara Ayala-Orozco ${ }^{1}{ }^{\mathbb{D}}$, Julieta A. Rosell ${ }^{2, *} \mathbb{C}$, Juliana Merçon ${ }^{3}{ }^{\mathbb{D}}$, Isabel Bueno ${ }^{4}$, \\ Gerardo Alatorre-Frenk ${ }^{5}$, Alfonso Langle-Flores ${ }^{6}(1)$ and Anaid Lobato ${ }^{5}$ \\ 1 Instituto de Investigaciones en Ecosistemas y Sustentabilidad, Universidad Nacional Autónoma de México, \\ Morelia CP 58190, Mexico; bayala@cieco.unam.mx \\ 2 Laboratorio Nacional de Ciencias de la Sostenibilidad, Instituto de Ecología, Universidad Nacional \\ Autónoma de México, Mexico City CP 04510, Mexico \\ 3 Coordinación Universitaria para la Sustentabilidad, Universidad Veracruzana, Xalapa CP 91090, Mexico; \\ jmercon@uv.mx \\ 4 Posgrado en Ciencias de la Sostenibilidad, Universidad Nacional Autónoma de México, \\ Mexico City CP 04510, Mexico; isabel.bogora@gmail.com \\ 5 Instituto de Investigaciones en Educación, Universidad Veracruzana, Xalapa CP 91097, Mexico; \\ geralatorre@gmail.com (G.A.-F.); anaid.lobato@gmail.com (A.L.) \\ 6 Centro de Investigación y Docencia Económicas, Sede Región Centro, Aguascalientes CP 20313, Mexico; \\ alfonsolangle@gmail.com \\ * Correspondence: julieta.rosell@iecologia.unam.mx; Tel.: +52-55-5623-7718
}

Received: 30 July 2018; Accepted: 4 September 2018; Published: 8 September 2018

\begin{abstract}
Addressing complex environmental problems requires the collaboration of stakeholders with divergent perspectives, a goal that is challenged by diverse factors. Challenges hindering multi-stakeholder collaboration (MSC) for sustainability have previously been addressed in the context of transnational partnerships. However, less is known regarding how place-based MSC operates, especially in the context of the Global South. To contribute to addressing the factors that hinder place-based MSC for sustainability in the Global South, we analyzed 38 MSC projects spanning diverse ecological and social contexts across Mexico. In a series of participatory workshops, 128 stakeholders from academia, government, business, local communities, and civil society organizations discussed factors that hinder place-based MSC and co-constructed strategies to strengthen collaboration. Some challenges coincided with those identified in previous studies (e.g., divergent visions, inadequate project planning), whereas other concerns that have not been commonly regarded as important emerged as crucial obstacles for MSC. We discuss these challenges in the context of areas of limited statehood and point to the traditions of popular education and participatory action research as a source of valuable tools for place-based MSC. We identify strategies capable of addressing diverse challenges, a result that could aid prioritizing resource allocation to strengthen MSC.
\end{abstract}

Keywords: multi-stakeholder collaboration; limited statehood; network analysis; partnerships; sustainability; transdisciplinary collaboration

\section{Introduction}

The complexity and severity of environmental problems, such as climate change, biodiversity loss, pollution, ocean acidification [1,2], and interconnected problems, such as water and food security, exceed the capacities of a single sector of society [3-5]. Implementing appropriate solutions 
to these problems requires the collaboration of actors beyond scientists, including government, civil society organizations (CSOs), local communities, and businesses. Though some drawbacks are acknowledged [6-9], multi-stakeholder partnerships are for the most part regarded as crucial in efforts toward sustainable development [10-14].

Multi-stakeholder partnerships for sustainability are collaborative arrangements in which actors from different sectors of society work together toward a sustainability goal [15]. Within such partnerships, multi-stakeholder collaboration (MSC) refers to the interactive process in which actors with diverse points of view work together, implementing collective action, and sharing risks, resources, and responsibilities [16-19]. Diverse transdisciplinary research approaches have been proposed by the academic sector to achieve sustainability goals. In these transdisciplinary processes, in which stakeholders jointly define the research problem to be addressed, incorporate their diverse perspectives in co-produced solution-oriented knowledge, and put this new knowledge into societal and scientific practice [20-22], MSC is always present. For the purpose of this work, we focus on collaboration between diverse stakeholders and the factors that hinder such collective work, in which different logics, values, interests, and knowledge systems need to converge [23-25].

Understanding the factors that hinder MSC and strategies to overcome these challenges is crucial for effective contribution of these collective processes to sustainability. Challenges to MSC for sustainability have been addressed, often focusing on perspectives at the national or transnational levels $[6,18,21,26-30]$. Stemming from analyses of multi-stakeholder partnerships, general guidelines for MSC have been published by academic institutions [31], businesses and CSOs [32,33], as well as by government agencies [34,35]. Much of this insight regarding MSC has been gained from partnerships at the national and transnational levels $[6,9,29,36,37]$. Such high-level partnerships have been recognized as a new form of global governance for sustainable development, negotiating political regulations and assisting in policy implementation in a multi-level governance system [38]. Further increasing interest in transnational MSCs, the 2030 Agenda for Sustainable Development established multi-stakeholder partnerships as key in achieving sustainable development goals (Goal 17, target 17.16, [14]). It thus seems clear that high-level MSC has a significant role to play in global sustainability, and that much of our understanding regarding the challenges and strategies to establish MSCs has been gained from these experiences.

In contrast with transnational partnerships, less has been discussed regarding how place-based partnerships for sustainability operate, especially in the Global South. Place-based MSCs are those focused on addressing an issue at the local scale and are designed to meet the needs of a particular context by drawing on local assets [39]. Taking into account the unique characteristics of a given social-ecological system [40], place-based MSC aims to generate locally relevant knowledge and context-specific solutions to address sustainability problems [41]. Efforts have been made to propose general principles for carrying out place-based MSCs [31,39,42], but the absence of comprehensive assessments covering a wide range of contexts still hinders the design of effective place-based collaborations. While the formulation of these guidelines has included insight from experiences in diverse areas of the Global South, the political, cultural, and economic factors of these contexts and their effect on MSC have been little discussed (though see [37]). Challenges for MSC in the contexts of the Global South (e.g., with weak institutions and public insecurity [43]) could differ in important ways from those prevailing in other regions of the world. Finding that these challenges differ from those in other regions of the world would highlight the obstacles to implementing similar strategies and partnership designs across contexts. Moreover, these differences would focus attention to the need to integrate the contexts and experiences of place-based MSC from the Global South more thoroughly in discussions of global sustainability [44].

To contribute to addressing the factors that hinder place-based MSCs for sustainability in the Global South, we analyzed MSC experiences across Mexico. A set of 38 MSC experiences allowed us to identify common themes across their varied ecological and social contexts, as well as commonalities and differences with studies from other geographic areas and from high-level national and transnational 
levels. Mexico provides an ideal system for examining place-based MSC in the complex ecological, social, and political context shared by most Latin American countries and other regions of the Global South. With approximately $10 \%$ of the world's biodiversity [45] and seven million speakers of 72 indigenous languages [46], Mexico is extremely biologically and culturally diverse [47], a condition shared by other countries of the Global South. At the same time, Mexico experiences high rates of land use change, which have led to severe levels of ecosystem degradation affecting human well-being [45]. In addition, Mexico is a country with enormous disparities of power and wealth, where truly democratic participation is still under construction, and also a country with large areas of limited statehood, all conditions with a strong presence in the Global South $[48,49]$. To examine which of these and other factors emerge as important challenges in place-based MSC in Mexico, we surveyed 38 projects working on a wide diversity of sustainability topics. In a series of participatory workshops, stakeholders collaborating on these projects discussed challenges faced in their place-based MSCs and strategies to overcome them. Based on these collective discussions, we categorized challenges and strategies and used network analysis to examine how they were associated. Network analysis pinpointed strategies able to deal with a wide variety of challenges, helping guide efforts and use of resources in place-based MSCs.

This approach allowed us to identify numerous common themes spanning the diverse place-based MSCs we surveyed and highlighted important similarities and differences with perspectives from other areas of the world. We identified divergent visions and interests across stakeholders and inadequate project planning and management as major obstacles of place-based collaborations, paralleling the concerns identified in previous literature on MSC. These important points of parallelism suggest the possibility of sharing strategies to foster MSC across contexts, and even their scalability across levels. We also identified cultural and political factors representing formidable obstacles for MSC in Mexico, and likely in other Global South contexts as well, which have been little discussed in the literature despite their potentially significant effect on sustainability efforts. Particularly salient are issues associated with limited statehood, such as public insecurity, corruption, and limited infrastructure, which severely affect the contexts in which place-based MSC can be carried out. We underscore that taking into account such factors explicitly is crucial when designing strategies and partnerships for effective place-based MSC. We conclude by discussing the ways in which two related frameworks that originated in Latin America, Popular Education (PE) and Participatory Action Research (PAR), can provide conceptual and methodological resources for carrying out place-based MSC in culturally, politically, and environmentally troubled contexts of the Global South.

\section{Materials and Methods}

\subsection{Project Selection and Workshops}

In July 2015, we issued a nationwide call for participants in ongoing place-based sustainability projects with a social-ecological approach (Figure 1a, Table S1). We selected projects that had involved MSC for at least two years and that included at least two, preferably three, out of five different sectors in the partnership: academia, government, business, CSO, and the local community (Figure 1b). Although the specific composition of stakeholders can have a strong influence on the way collaborations are carried out [18], we did not guide project selection by any specific combination of collaborating sectors. As a result, projects represented practically all potential combinations of sectors (Table S1). The 38 projects covered a geographic spread that was maximally wide within the country (Figure 1a), and spanned a wide range of themes, from conservation and ecological restoration, agroecology, community-based natural resources monitoring, collaborative governance for resource management, to environmental justice and human rights (Figure 1c). Each project selected three to five of its members from different sectors to attend a workshop aimed at discussing MSC experiences working toward environmental sustainability. 


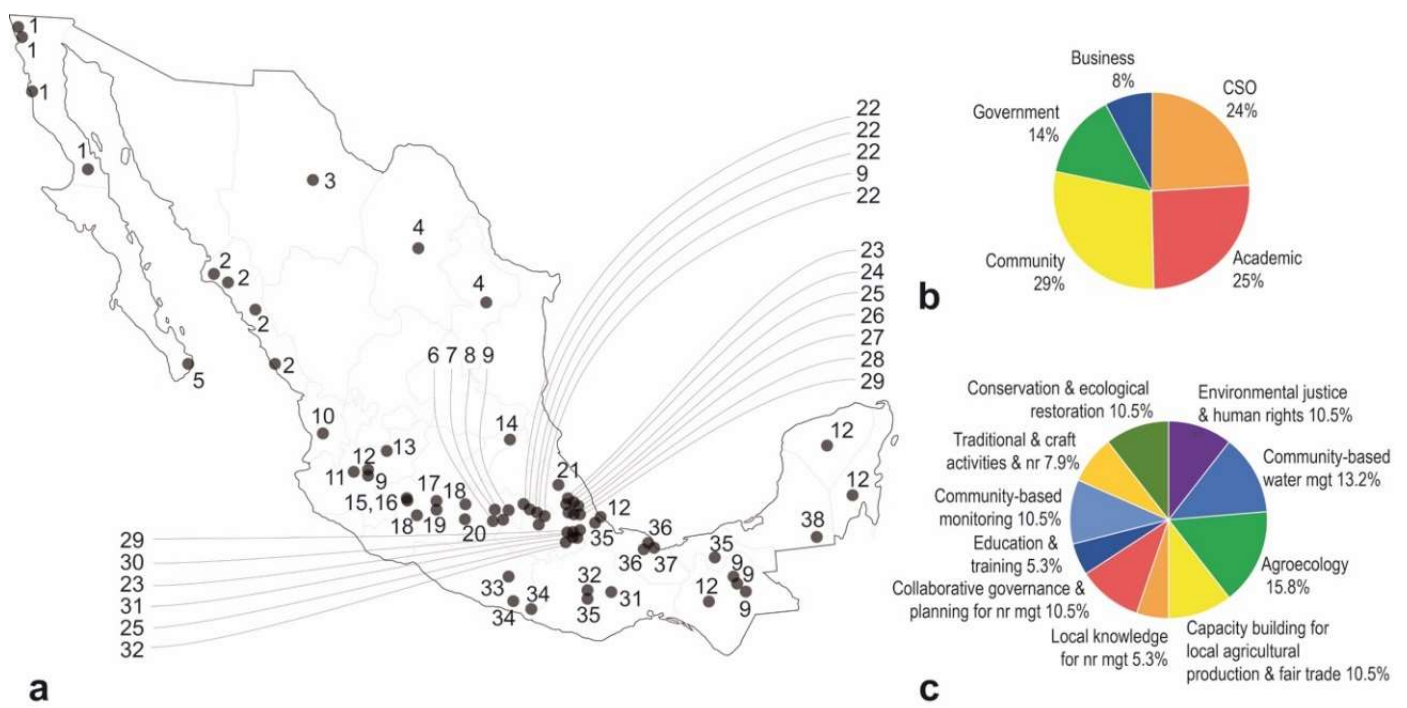

Figure 1. Location of projects (a); distribution of the 128 participants by sector (b); and diversity of project topics (c). Full information of projects is included in Table S1 based on project numbers (a).

Three four-day participatory workshops [50-52] were carried out with 40-45 participants each. The aim of these workshops was to identify and discuss factors that have hindered MSC within each project, as well as strategies to address these factors to strengthen MSC. These strategies included proven ones already implemented within projects as well as new ones co-created in the workshop. Previous studies have also implemented participatory methods, including workshops, to engage participants in collective reflection regarding sustainability problems and solutions [53,54]. Based on the principle that "we learn from each other together" and that "we can learn more from each other if we do not all think alike or act alike" [55] (p. 11), activities were carefully designed to foster discussion in working groups with a heterogeneous composition of sectors [51].

To discuss factors hindering place-based MSC, participants were grouped by project and they were asked to describe their project's main objectives and the sectors involved in the collaboration. Based on the project experience, group members listed factors that had challenged collaboration. Discussions were guided by a facilitator, who recorded and transcribed the dialogues. The facilitation team was made up of an interdisciplinary group of academics and members of CSOs. Factors hindering MSC were grouped in topics by facilitators during workshops. Choosing one of these topics, participants formed groups to co-create strategies to overcome these challenges hindering place-based MSC. Participants provided written informed consent at the beginning of workshops. The study was conducted following the National Autonomous University of Mexico Code of Ethics [56].

To foster a climate of trust and productive exchange between participants, workshops included activities aimed at enhancing active listening and openness, including ice-breaking activities and gatherings in which project experiences were exchanged [57]. These activities encouraged new personal and professional connections between participants.

\subsection{Data Analysis}

Based on the challenges for place-based MSC mentioned by participants, we constructed a typology with open coding [58-60]. We started with a set of codes that were modified as we went through the data to ensure maximal internal homogeneity within categories and external heterogeneity across categories [61]. Following the same procedure, we constructed a typology of the strategies proposed in the workshops. To allow for fine analysis of the data, especially for network analysis (see below), our typology included categories divided into subcategories. We calculated frequencies for each category and subcategory of challenges and strategies, and interpreted percentages as a reflection 
of the factors present in participant discussions, but not as an indication of how important these factors were for participants or their collaborative efforts.

We used network analysis [62] to examine how factors that hinder place-based MSC were associated with strategies to overcome them. We built a directed network with weights between the ten subcategories of challenges and the twenty subcategories of strategies [63], which made up the nodes of the network. We used subcategories instead of categories to provide more resolution of the relationships between challenges and strategies. A node (subcategory) of strategies and a node (subcategory) of challenges were connected if at least one strategy in that subcategory was mentioned as a way to overcome a particular challenge in the other subcategory. We calculated the indegree for each strategy node as the number of inward ties from challenge nodes. We used the number of strategies for each challenge subcategory as the weight of each tie. For example, participants proposed seven communication strategies to cope with the challenges in the subcategory divergent visions. As a result, there was one tie between the nodes divergent visions and communication with a weight of seven. Finally, to identify key subcategories of strategies able to address many types of challenges, we used the centrality of strategy nodes and the strength of their connections (weight). High centralities and weights highlighted strategies with high levels of connectivity and thus able to address a wide variety of challenges in MSC. We calculated network metrics with UCINET [64] and visualized networks with Gephi [65].

\section{Results}

\subsection{Diversity of Workshop Participants and Projects}

A total of 128 participants in 38 projects throughout Mexico attended the three workshops (Figure 1a, Table S1). Most participants belonged to local communities (29\%), academic institutions $(25 \%)$, or CSOs (24\%) (Figure 1b). Government stakeholders represented $14 \%$ and mainly included representatives of local governments, managers of protected areas, and staff of national government research institutions. A small percentage of participants belonged to businesses ( $8 \%$ ), all of which were social enterprises.

\subsection{Challenges Hindering Multi-Stakeholder Collaboration}

Factors hindering place-based MSC were grouped into five overarching categories and ten subcategories (Table 1). Factors associated with divergent visions and interests across sectors and stakeholders were the most frequently mentioned difficulties (32.5\%, Table 1). Participants highlighted that divergent objectives, interests, and priorities caused tensions, unbalanced stakeholder participation, weak MSC, and mistrust between collaborators. In addition, the cultural diversity of Mexico, expressed by its high number of indigenous groups, was also mentioned as a factor leading to strikingly divergent worldviews. Participants also mentioned tensions with specific sectors, mainly academia and government. For example, large gaps were perceived between stakeholder needs and academic and government programs. Divergent visions and interests challenged all stages of place-based MSC, but were particularly limiting for the definition of common goals and agendas, a crucial first stage in MSC.

Inadequate planning and project management also held back place-based MSC (26.3\%, Table 1). Lack of continuity of programs and projects, lack of funding and personnel, and differences in time frames across sectors (e.g., the duration of an academic project or the annual periodicity of funding cycles) were perceived as severe challenges for carrying out place-based sustainability projects. These projects usually yield results in the mid or long term, whereas some stakeholders often desire shorter time frames. 
Table 1. Challenges hindering multi-stakeholder collaboration.

\begin{tabular}{|c|c|}
\hline Category and Subcategories (\%) & Examples \\
\hline \multicolumn{2}{|c|}{$\begin{array}{l}\text { I. Divergent visions and interests (32.5\%). Different objectives, interests, and ideologies causing tensions across sectors and } \\
\text { stakeholders }\end{array}$} \\
\hline \multirow[t]{2}{*}{ 1. Divergent visions ( $16.3 \%)$} & $\begin{array}{l}\text { The visions of some stakeholders that do not empathize with } \\
\text { indigenous worldviews }\end{array}$ \\
\hline & $\begin{array}{l}\text { Logic of individualism that hampers the integration of the } \\
\text { group }\end{array}$ \\
\hline \multirow[t]{3}{*}{ 2. Tensions within and between sectors $(16.3 \%)$} & $\begin{array}{l}\text { Interests of CSOs do not coincide at times with those of } \\
\text { community members }\end{array}$ \\
\hline & $\begin{array}{l}\text { Mismatch between rhetoric and practice of certain } \\
\text { government agencies }\end{array}$ \\
\hline & $\begin{array}{l}\text { Lack of integration, coordination, and professional ethics of } \\
\text { some academic actors }\end{array}$ \\
\hline \multicolumn{2}{|c|}{$\begin{array}{l}\text { II. Inadequate planning and project management }(26.3 \%) \text {. Methodological and logistical challenges leading to poor project } \\
\text { management }\end{array}$} \\
\hline \multirow[t]{3}{*}{$\begin{array}{l}\text { 1. Differing timeframes and lack of project continuity } \\
(15.8 \%)\end{array}$} & $\begin{array}{l}\text { Students do not provide follow-up to projects after } \\
\text { graduation }\end{array}$ \\
\hline & Limited time and capacity for monitoring activities \\
\hline & $\begin{array}{l}\text { Timing differences between sectors participating in the } \\
\text { projects }\end{array}$ \\
\hline \multirow[t]{2}{*}{ 2. Insufficient funding and personnel (10.5\%) } & Lack of funding sources \\
\hline & $\begin{array}{l}\text { The small size of the facilitating team makes it impossible for } \\
\text { them to work in more communities }\end{array}$ \\
\hline
\end{tabular}

III. Inadequate organization among stakeholders (18.7\%). Limited participation in decision-making and inadequate stakeholder and institutional organization leading to challenges in MSC

\begin{tabular}{ll}
\hline $\begin{array}{l}\text { 1. Limited participation and inadequate organization } \\
\text { among stakeholders }(13.9 \%)\end{array}$ & $\begin{array}{l}\text { Dialogue spaces often lack credibility from the perspective of } \\
\text { communities }\end{array}$ \\
\hline 2. Inadequate institutional organization $(6.2 \%)$ & Dependence on community leaders, little grassroots action \\
\hline & $\begin{array}{l}\text { High levels of bureaucracy } \\
\text { Traditional decision-making structures do not represent all } \\
\text { community members }\end{array}$ \\
\hline
\end{tabular}

IV. Problems of communication and lack of information (13.9\%). Inadequate communication across sectors and lack of suitable information hindering project development

Lack of partnership with other organizations; there is no communication and no information sharing

Lack of understanding of the social context in the national park by government actors

Language differences that hinder agreements (e.g., Tseltal and Spanish)

V. Structural conditions (8.6\%). Territorial, economic, and socio-political aspects setting conditions in which collaborations take place

1. Social, political and economic system (5.3\%)

2. Discrimination $(1.9 \%)$

3. Public insecurity (1.4\%)
There is no local market for the product. The market is controlled by the demand of large businesses that do not give preference to local varieties

Male farmers are less likely to interact with female rather than male extension agents

Lack of safety, violence, and organized crime in the municipality

Differences in organizational cultures of stakeholders and institutions were perceived as important factors hindering collaboration and were grouped in the category inadequate organization among stakeholders (18.7\%, Table 1). Different organizational cultures led to a lack of clarity regarding objectives and responsibilities, to unbalanced participation and leadership, and to a lack of credibility among 
stakeholders. In combination, these conditions led to disagreement, or even conflict, damaging social capital. In addition to poor organization, place-based MSC was hindered by poor communication across stakeholders.

Problems of communication and lack of information were present from the initial phase of delimiting common objectives and goals, to the stage of dissemination of results $(13.9 \%$, Table 1$)$. Communication was challenged by manifold factors, including the use of specialized jargon or of different languages (e.g., Spanish vs. indigenous languages), a lack of understanding of the local social and ecological contexts (e.g., by government representatives), or even by the rugged topography of Mexico and roads in bad condition, which complicated information exchange within and across projects.

Finally, challenges reflecting structural conditions of Mexico, likely shared by other countries in Latin America and the Global South, were also mentioned in the workshops (8.6\%, Table 1). Structural conditions refer to socio-political, economic, and territorial conditions in which MSC takes place. Factors in this category included strong discrimination against indigenous communities and women, political transitions resetting government programs and representatives (i.e., winner-takes-all municipal political system), electoral processes causing turmoil and violence, and stakeholder emigration from local communities due to economic and insecurity reasons. Public insecurity and violence appeared as additional factors that imposed difficult conditions for place-based MSC in Mexico.

\subsection{Strategies to Foster Multi-Stakeholder Collaboration}

Participants in the workshops mentioned a very wide range of strategies to foster place-based MSC. A quarter of all strategies focused on developing capacities for better project management (24\%, Table 2). Different ways of systematizing, monitoring, and evaluating projects, as well as increasing accountability, improving access to funding, and improving management of human and financial resources, were mentioned. With the goal of improving project management, strategies to foster participation in decision-making and collective action were also proposed. In addition to practical aspects, strategies also addressed the complexities of constructing a common vision across stakeholders.

Table 2. Strategies to foster multi-stakeholder collaboration.

\begin{tabular}{|c|c|}
\hline Categories (\%) & Examples \\
\hline \multicolumn{2}{|l|}{ A. Project management (24\%) } \\
\hline $\begin{array}{l}\text { 1. Project planning } \\
\text { Strategies to improve project planning and } \\
\text { operation }\end{array}$ & $\begin{array}{l}\text { Generate clear project guidelines } \\
\text { Establish the agendas and commitments for each level of } \\
\text { decision-making } \\
\text { Produce an organizational chart of the project team }\end{array}$ \\
\hline $\begin{array}{l}\text { 2. Funding management } \\
\text { Strategies for effective management of } \\
\text { economic resources and identification of } \\
\text { funding sources }\end{array}$ & $\begin{array}{l}\text { Include the cost of outreach activities in project budgets } \\
\text { Include strategies for funding management in participatory } \\
\text { planning } \\
\text { Generate sources of self-employment through productive projects }\end{array}$ \\
\hline $\begin{array}{l}\text { 3. Systematization, monitoring, and } \\
\text { evaluation } \\
\text { Strategies focused on generating processes } \\
\text { of systematization, monitoring, and } \\
\text { evaluation }\end{array}$ & $\begin{array}{l}\text { Devise supervision strategies that help meet project goals } \\
\text { Conduct periodic internal and external evaluations } \\
\text { Document and systematize the progress of the project } \\
\text { Ensure that planning, monitoring, and evaluation are conducted in a } \\
\text { participatory manner }\end{array}$ \\
\hline $\begin{array}{l}\text { 4. Accountability and transparency } \\
\text { Strategies to strengthen transparency and } \\
\text { accountability to enforce sanctions when } \\
\text { agreements are not complied with }\end{array}$ & $\begin{array}{l}\text { Implement mechanisms for transparency (e.g., websites) } \\
\text { Enhance monitoring and accountability with reports on resource } \\
\text { management and meetings } \\
\text { Enforce economic or legal sanctions when there is a lack of } \\
\text { compliance } \\
\text { Report obstacles and achievements }\end{array}$ \\
\hline
\end{tabular}


Table 2. Cont.

B. Construction of a common vision $(19.6 \%)$

Make clear the mutual interests and what we wish to achieve collectively

1. Construction of common objectives and Produce together an action plan and establish a common vision and social cohesion. Strategies to define common objectives and foster the development of collective identity objectives

Agree on the forms of and spaces for collective work

Implement mechanisms of prevention, attention to, and resolution of conflicts Create a common language

2. Formation of alliances Strategies to foster relationships among strategic stakeholders and sectors

3. Formalization of collaboration Strategies to promote formal agreements and structures for collaboration

4. Partnerships with government and academia

Strategies for collaboration with government actors and researchers

5. Inclusive practices Strategies to foster the participation of minority and vulnerable groups

C. Capacity building and tools (15\%) Strategies to foster learning and abilities in stakeholders

2. Methodological tools Strategies for collective analysis and to facilitate collective work

3. Consultancy

Strategies to integrate specialized consultancy in projects

D. Communication (14.8\%)

1. Communication and information Strategies to strengthen communication channels and to promote dialogue and information exchange across stakeholders
Identify strategic intra- and cross-sectoral alliances

Work in networks of collaboration and support

Approach regional organizations and governmental institutions that address the same issues

Establish long-term agreements of collaboration, with clear objectives and goals

Create formal bodies with stakeholder representation

Create citizen's committees for outreach that favor interaction among stakeholders

Form inter- and trans-disciplinary working teams

Establish collaborations between academics and communities to undertake processes of participatory research

Contact researchers and establish agreements based on affinities and commitments

Generate activities and projects for different groups within the community to integrate children, young people, women, and seniors Encourage the leadership of women and young people Establish project guidelines with gender equality Create common languages and forms of participation for the integration of marginalized groups

\section{Identify stakeholders who wish to learn}

Support extension agent training

Provide training and tools through participatory workshops in topics of evaluation, resource management, political action, accountability, human rights, and international law Establish channels for the transmission of different knowledge systems

Stakeholder mapping (sociogram) to visualize relationships and analyze power balance

Conduct a diagnostic to determine factors of social dissolution within a community (e.g., political, electoral, deep-rooted customs) Identify, in a participatory manner, problems, needs, and alternatives, taking language and traditions into account

\section{Request legal advice}

Seek mechanisms of linkage with programs of government, universities and CSOs to launch projects Seek advice regarding organizational development

Build a common language across stakeholders In multilingual contexts, ensure translation and learn local languages

Hold periodic meetings so that all stakeholders have the same level of information and knowledge of the project Inform in a clear and transparent, organized, and appropriate way, and in line with group meeting decisions Increase public visibility of projects in communication media Encourage independent media (e.g., community radio stations) Use suitable media to improve information dissemination 
Table 2. Cont

2. Partnership-building spaces Strategies to create spaces suitable for promoting partnerships amongst sectors
Promote spaces of dialogue (e.g., forums, fairs, exchanges) for understanding different styles of reasoning

Organize gatherings with active participation and equality of conditions

Organize recreational activities to foster integration

E. Forms of organization and community institutions (13.5\%)

1. Functions and attributions Strategies to establish roles, functions, and mechanisms for decision-making

2. Community institutions and empowerment Strategies to recognize modes of organization and distribution of power within communities

\section{Bridging stakeholders} Strategies to train individuals and institutions with bridging capacities (e.g., for translation or communication) across sectors
Define mechanisms for decision-making

Rotate roles to generate empathy with other individuals and

working groups

Clearly define responsibilities and activities of each stakeholder

Create spaces to manage problems and conflicts

Recognize and respect community organization structures, traditions, and customs

Foster organization and autonomy based on a community's traditional systems of governance

Foster diverse forms of collective community work

Establish agreements within community assemblies

Foster community development plans on which governmental intervention can be based

Identify a person in charge of outreach and communication activities of the project

Enhance the role of CSOs and academics as mediators for dialogue between the community and the government.

Choose individuals that are empathetic and capable of building trust in meetings with other sectors

F. Values and attitudes $(8.5 \%)$

Promote awareness and respect for the decision-making processes in each sector

Avoid taking conflicts to a personal level

1. Strategies to promote interpersonal relationships that favor collaboration, dialogue, and interaction

Respect differences

Recognize and highlight different capacities, forms of knowledge, and ways of life

Foster collaboration and action across sectors through gatherings

and meetings

Foster equality and trust

G. Government and governability $(4.6 \%)$

1. Government programs
Strategies to improve government programs and their relevance based on real social needs

\author{
Demand that government programs respond to the needs of society \\ Reassess criteria and guidelines of public programs \\ Coordinate government programs that are directed at the same type \\ of projects (health, environment, etc.) \\ Report crimes to the police \\ Report crimes to the police when the conditions make it safe to do so \\ [for example, collusion between police and organized crime can \\ make reporting crimes dangerous] \\ Always carry an institutional identification instead of only a \\ personal ID [because of regard for some institutions, e.g., \\ universities, showing such an ID could earn leniency] \\ Resort to legal bodies and legal instruments for the defense of \\ human rights \\ Create armed community self-defense groups
}

2. Public security Strategies to deal with public insecurity caused by crime and violence

Diverse strategies for the construction of a common vision, that is, to identify common interests and to build shared objectives, were mentioned (19.6\%, Table 2). Participants emphasized the importance of formal agreements, especially when collaborating with government and academics, building common knowledge across stakeholders, designing mechanisms for preventing and solving conflicts, and establishing strategic alliances and partnerships, especially with academics and government. Engagement of minorities and vulnerable groups in MSC was perceived as paramount, because inclusivity helps build a common vision. Following the process of building common goals, a lack of 
abilities and training in different areas, and poor communication commonly hindered place-based MSC according to our results. Participants mentioned several strategies to face these challenges.

Strategies regarding capacity building and tools and to improving communication represented $15 \%$ of total mentions each (Table 2). Key capacities included those aimed at fostering participatory processes and community development, increasing the political impact of a project (for example, obtaining additional funding or scaling of the project to regional levels), and improving project management and accountability. In some cases, participants emphasized the need to fill knowledge gaps through specialized consultancy regarding, for example, sustainable development, resource management, process evaluation, human rights, national and international law, partnership building, and organizational growth. Strategies to address communication challenges included building a common language, using diverse communication media (e.g., social networks, community-based radio, etc.), and improving the way in which communication takes place, for example, fostering empathy and transparency. Organization of different kinds of meetings (forums, fairs, etc.) was regarded as a way of allowing direct communication between stakeholders and projects.

Many strategies were grouped in the category forms of organization and community institutions $(13.5 \%$, Table 2). This category included strategies for the distribution of power within local communities or across sectors, and the establishment of clear agreements regarding the division of tasks and responsibilities, decision-making mechanisms, sanctions in case of breach of obligations, and mechanisms for conflict resolution within communities. Participants highlighted the importance of understanding and respecting traditional forms of community organization, of voluntary collective work within communities, and of including key actors in MSC who can link sectors. In turn, the category of values and attitudes $(8.5 \%$, Table 2$)$ included strategies for enhancing interpersonal relationships in the context of collaboration, including ways of fostering trust, equity, commitment, and respect for diverse points of view in the context of stakeholder diversity.

Finally, with $4.6 \%$ of mentions, participants proposed strategies for overcoming structural and political challenges, which were included in the category government and governability (Table 2). Although these factors go beyond MSC, they do set the context for collaboration, and, as a result, they strongly influence how sustainability projects are carried out and their outcomes. Participants proposed strategies to modify guidelines of government programs, and also to better coordinate these programs between government sectors. Proposed changes were aimed at fostering community autonomy and at reducing the extreme bureaucracy that characterizes government institutions. Another set of important structural conditions were public insecurity and violence. In this regard, participants proposed strategies for prevention of crime and violence, and insisted on the importance of denouncing acts of aggression and violence to the authorities, though the participants reported that they do not always do so. For cases in which public insecurity has become the norm, profound structural and organizational transformations were suggested, such as vigilante self-defense groups.

\subsection{Network Analysis}

The twenty strategy subcategories were connected with the ten challenge subcategories through 131 ties (Figure 2). Most subcategories of challenges were addressed by multiple subcategories of strategies, which was reflected by the average number of ties (i.e., the mean degree) of 6.5 . Values and attitudes had the highest degree (nine ties), followed by seven other subcategories with eight ties (i.e., capacity building and learning, project planning, communication and information, community institutions and empowerment, common objectives and social cohesion, formation of alliances, functions and attributions). In contrast, consultancy, inclusive practices, and public security addressed only two challenge subcategories (Figure 2). Regarding the weight of ties, certain challenges were strongly linked to specific subcategories of strategies (thick arrows in Figure 2), reflecting that many strategies were proposed by participants to address that kind of challenge. This was the case of communication and information and also insufficient funding and personnel. Although a few specific subcategories of 
strategies can address specific subcategories of challenges, most strategies can cope with myriad different challenges.

Challenges

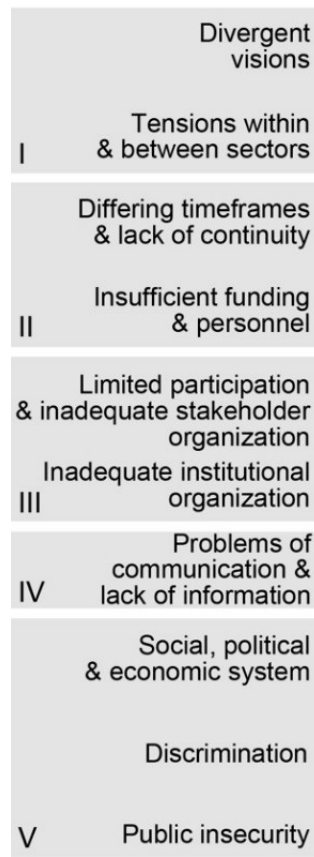

\section{Strategies}

Project planning
Funding management
Syst., monitoring \& evaluation
Accountability \& transp. A
Common object. \& cohesion
Formation of alliances
Formalization of collaboration
Partnerships with gov. \& acad.
Inclusive practices
Capacity building \& learning
Methodological tools
Consultancy
Communication \& information
Partnership-building spaces D
Functions \& atributions
Community institutions \& emp.
Bridging stakeholders
Values \& attlitudes
$\begin{aligned} & \text { Goverment programs } \\ & \text { Public security }\end{aligned}$

Figure 2. Network connecting subcategories (nodes) of challenges and strategies. Blocks represent categories of challenges (roman numbers) or of strategies (capital letters) (see Tables 1 and 2). Arrow width represents the weight of the tie (number of strategies proposed for each subcategory of challenge). Circles represent the indegree of strategy subcategory nodes (number of inward ties, i.e., number of challenge subcategories each strategy subcategory is connected with).

In the network, we detected four prominent subcategories of strategies concentrating $25 \%$ of the ties (33 of a total of 131) and almost $40 \%$ of their weight (number of strategies mentioned by participants, 161 of a total of 413). These strategies included project planning, capacity building and learning, values and attitudes, and communication and information. Two of these strategies, project planning, and capacity building and learning, were connected to more similar types of challenges, and as a result, appeared closer to each other in Figure 3. This result suggested a synergistic effect between these two groups of strategies, that is, implementing strategies included in project planning would have a synergistic effect with the implementation of strategies in capacity building and learning, given they address similar subcategories of challenges (Figure 3). In contrast, values and attitudes and communication and information appeared farther away from each other and also from the other two subcategories of strategies, suggesting that they were connected to more different types of challenges (Figure 3). As a result, implementing strategies from these categories would tend to have a complementary effect on MSC. 


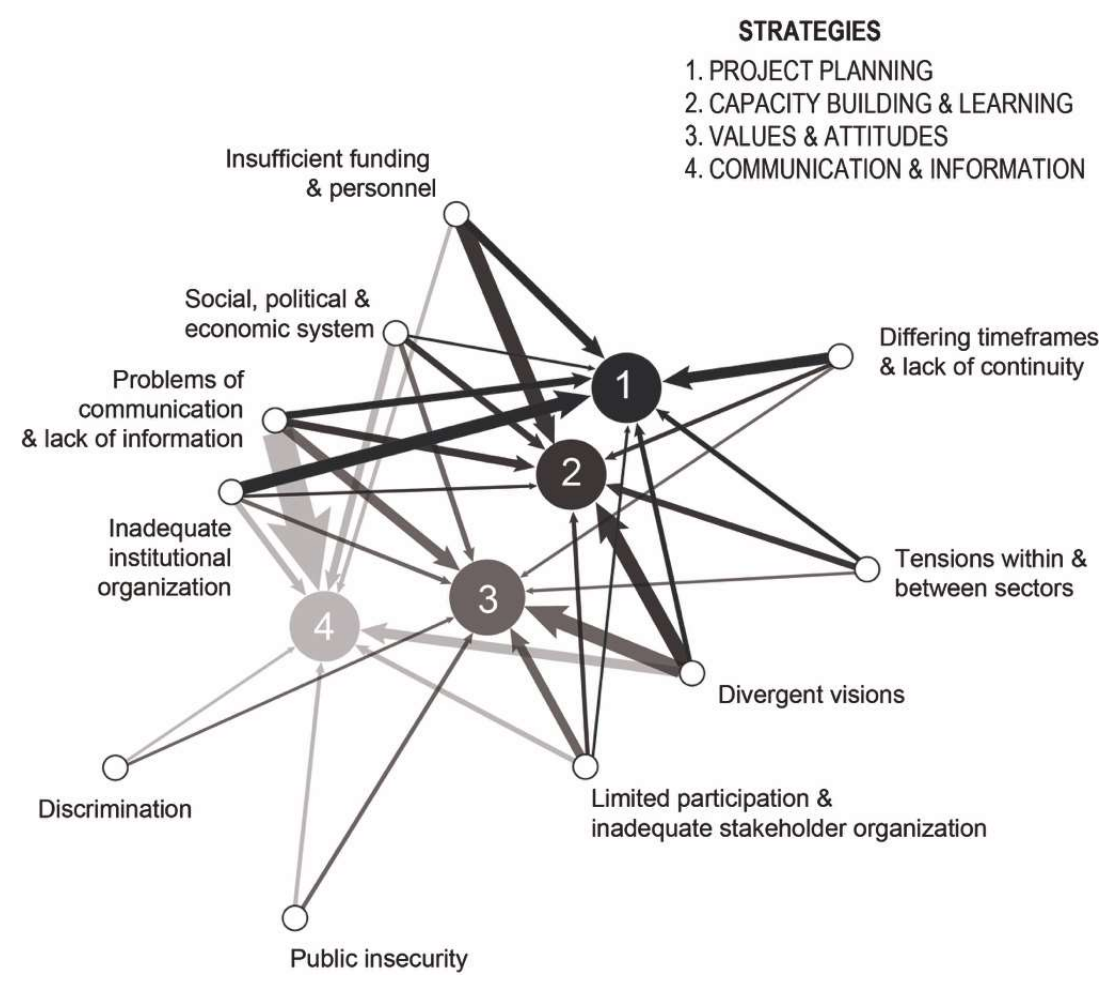

Figure 3. Key strategies to foster multi-stakeholder collaboration. These strategies were identified based on their high indegree and high weight of linkage with challenges (graph layout generated by the Yifan Hu Proportional algorithm).

\section{Discussion}

Our results examining place-based MSC sustainability projects across a vast diversity of social-ecological settings in Mexico highlighted remarkable coincidence between the challenges faced and the solutions implemented by the projects we surveyed and those discussed in the literature, as well as very important differences. We first focus on these differences, i.e., on the challenges likely characterizing MSC in many countries in the Global South, which have been largely overlooked in previous literature. We then address challenges and strategies for place-based MSC in Mexico that converge with discussions on place-based MSC in other areas of the world and also at transnational levels. Given the vast diversity spanned, including a range of ecosystems from coral reefs to lowland rainforests and desert highlands (Table S1), and stakeholders including indigenous communities, farmers, and social enterprises, our results are likely to be applicable to MSC even beyond Mexico. Along these lines, we focus attention on traditions of PE and PAR that originated in and remain well established in Latin America. We provide examples on how these frameworks offer conceptual and methodological resources for place-based MSC in contexts of the Global South. We conclude by indicating future directions.

\subsection{Challenges Hindering Place-Based MSC in Mexico: Structural Factors in a Country with Areas of Limited Statehood}

Place-based MSC is hindered by a great variety of challenges, some of which have been little addressed in previous MSC literature. These challenges have to do with structural conditions. These conditions are often contextual or "out of reach" of MSC projects, and hence were not as frequently mentioned as some other challenging factors (Table 1). However, participants still regarded them as crucial for carrying out place-based MSC in Mexico. Participants reported structural factors, such as socio-political and economic inequality, lack of social participation, discrimination, intercultural conflict, and generalized public insecurity as major obstacles to their sustainability projects. Public insecurity and violence can limit social participation [66], whereas organized crime 
can severely jeopardize outcomes of sustainability efforts [67] and has been shown to drive major environmental changes in several areas in Mexico (e.g., [68]). Because so many partnerships collaborate under these conditions in Mexico and throughout the Global South [69], any critical analysis of MSC and environmental governance must address these deep-seated factors explicitly.

Some of the challenging structural factors highlighted by participants are strongly aligned with a situation of "limited statehood" [70,71]. Areas of limited statehood are defined as those "where central state authorities lack the capacity to uphold the monopoly over the means of violence and/or to enforce the law" [72] (p. 4). Of the structural factors in Table 1, violence and public insecurity linked to organized crime $[43,66]$ is diagnostic of limited statehood. In addition, other challenges mentioned by participants, such as lack of legitimacy (of government actors in particular), corruption, power imbalance, and limited infrastructure, are also strongly associated with limited statehood [73]. In contrast with consolidated statehoods of much of the Global North, in Mexico the lack of government capacity to satisfactorily address the demands of social and economic development and environmental management has led to the emergence of alternative governance strategies [74] involving the non-hierarchical collaboration of multiple actors of society. As suggested by the composition of most of the surveyed projects, place-based partnerships including non-governmental actors, such as local communities, academics, and CSOs have become central in environmental governance and the local provision of collective goods in Mexico, a situation that has also been observed in studies focused at transnational levels (e.g., [75]). Even with a limited state, governance of natural resources and environmental management can be successfully achieved [76], something that has been observed in some areas of Mexico (e.g., [77]). Understanding these particular forms of governance in areas of limited statehood is crucial for fostering MSC aimed at sustainability, both at the local and global levels [49]. Further understanding of place-based MSC in areas of limited statehood will likely reveal additional factors that have been underestimated in MSC studies in the Global North, or even in studies in areas of limited statehood, but focused on transnational partnerships. In higher level partnerships, some limited statehood issues could appear less important or might remain undisclosed by stakeholders. As a result, place-based approaches represent a largely missing but crucial perspective that could better inform sustainability efforts in areas of limited statehood at the global scale as well.

\subsection{Challenges Hindering Place-Based MSC Shared by Mexico and Other Contexts and Partnership Levels}

We now turn to the numerous challenges that emerged in our study of place-based MSC that are similar to those commonly identified in MSC for sustainability in other geographic areas and in higher level partnerships. Particularly salient among these, with $60 \%$ of mentions, divergent visions and interests and inadequate project planning and management were highlighted as prominent challenges hindering MSC. Previous studies have frequently stressed the difficulties of integrating divergent perspectives in a partnership $[6,18,27,28,78,79]$, challenges that were also mentioned by workshop participants in our study (divergent visions and interests, Table 1). Divergent visions across stakeholders can mean that some stakeholders perceive a given sustainability problem while others do not perceive a problem at all $[21,27]$, leading to stalling of sustainability partnerships from the beginning. Regarding the obstacles that emerged from inadequate project planning and management, insufficient time, space, resources, and the lack of monitoring and evaluation throughout the collaboration have been addressed as important factors negatively affecting MSC in high level partnerships [6,29], and in our survey as well. Obstacles regarding project management and building a common vision are challenges that are inherent to cross-sectoral collaboration, and as a result, they are to some degree independent of social-political or economic contexts or of levels at which partnerships operate. These examples of agreement suggest rich opportunities for solutions to deal with these challenges to inform the implementation of MSC across geographic contexts and also across levels [31].

Other challenges mentioned by workshop participants previously discussed in the MSC literature could be particularly salient in the Mexican context and that of other countries in Latin America and the rest of the Global South. Prominent among these challenges were limited participation 
in decision-making and inadequate institutional organization (included in the category inadequate organization among stakeholders, Table 1). The ability of stakeholders to participate in a collaboration and to influence decision-making depends on their relative power to bring their concerns into the discussion [6]. Large power asymmetries can lead to a lack of trust among stakeholders $[9,80,81]$ or to illegitimacy $[21,79,82]$, something brought up in our workshops, especially when discussing collaboration with government actors. In the context of power imbalance, superficial or simulated forms of participation are likely to arise (passive participation [83]; symbolic participation [84]), resulting in low innovative potential of the partnership [27]. Although power issues inevitably emerge in multi-stakeholder partnerships [24,85], their negative effects on stakeholder participation [86] could be particularly strong in collaborations with vulnerable or marginalized groups. Many of the projects surveyed collaborated with indigenous populations. Even in the context of partnerships with horizontal collaboration schemes, power unbalances associated with the legacy of colonialism [87-91] are latent risks of partnerships involving indigenous communities. In a global situation in which indigenous populations are crucial actors in the management of natural resources in the Global South [92,93], understanding how MSC can be effectively carried out in conditions of equality and respect with these historically marginalized groups is of paramount importance [94-96].

\subsection{Fostering Key Strategies to Address Prevalent Challenges in MSC}

Network analysis showed that most subcategories of strategies (Table 2) can be implemented to deal with a great variety of challenges (Figure 2). Connectivity between challenges and strategies tended to be very high, with the degree of strategy nodes being eight or nine in many cases, close to the maximum value of ten (total number of challenge subcategories, and thus, the maximum number of potential inward ties, Figure 2). As a result of this high connectivity, strategies involving shifts in values and attitudes, for example, are able to address obstacles regarding divergent visions, limited participation, discrimination, as well as public insecurity (Figure 2). Likewise, strategies involving project planning can be implemented not only to improve project management or to deal with insufficient funding and insufficient personnel, but some of these strategies also allow for addressing divergent visions and problems of communication and lack of information, and to ease tensions within and between sectors. This high connectivity could reflect the high heterogeneity of experiences, perspectives, and values of the stakeholders in our workshops. This diversity was likely responsible for the wide span of strategies proposed for overcoming the same kind of challenge. Diverse perspectives in discussions has been shown to lead to a deeper understanding of the issue at hand and also to increase appreciation for the perspectives of others [86]. Here, the points of view of different social sectors were crucial to capture the complexity of MSC and to envision diverse ways of improving them.

Among ways of improving place-based MSC, network analysis allowed us to identify key strategies that can address most subcategories of challenges. These results could aid in prioritizing resource allocation that is aimed at strengthening MSC. These strategies were (i) project planning, (ii) capacity building and learning, (iii) values and attitudes, and (iv) communication and information (Figure 3). In combination, these strategy subcategories concentrated $40 \%$ of the proposed strategies and a quarter of the ties, highlighting their combined capacity to face most subcategories of challenges. Within this group of key strategies, project planning and capacity building and learning addressed similar types of challenges having a synergistic effect (thus their proximity in Figure 3). In a scenario of limited resources, these results suggest that managers would be advised to choose between strategies in project planning or capacity building and learning, given that they address similar subcategories of challenges. Remaining resources could be allocated to other key subcategories of strategies, mainly ones related to values and attitudes and to communication and information skills, which tend to address different subcategories of challenges in MSC (see ties in Figure 3). By identifying which sets of strategies best address different sets of challenges, our results thus can help make decisions regarding allocation of limited resources. 


\subsection{Resources for Place-Based MSC in the Global South and Beyond: Latin American Popular Education and} Participatory Action Research Traditions

Many of the projects surveyed, and also the structure of our workshops, drew on the traditions of Popular Education (PE) and Participatory Action Research (PAR) [97,98]. These approaches were forged in the turbulent social and political context of Latin America in the 1970s and offer a vast source of experience for place-based MSC throughout the Global South and beyond. These traditions focus on learning processes and social transformation through critical analyses of social reality with active participation of stakeholders [99-102]. Aiming at social change through horizontal forms of collaboration, both PE and PAR offer a framework for reflexive action (praxis) in contexts in which the established power structures have generated social and environmental injustice [103,104], as is often the case in Latin America and many areas in the Global South [105]. Under the general principles of PE and PAR, in MSC knowledge co-production, social learning, and action are tightly linked. Some principles that guide PE and PAR include the participation of marginalized groups in the design and execution of learning and research processes, as well as the generation of collective agreements on the objectives of knowledge and social change. These principles contribute significantly to the construction of a common vision among multiple stakeholders [106], capacity building, and effective communication [107], all of which have been identified in our study as strategic areas for MSC. Moreover, the strong focus of PE and PAR on social participation contribute to transforming entrenched power asymmetries [108], one of the most important challenges in place-based MSC in the Global South. PAR approaches have been implemented in MSC for natural resource management [109], climate change adaptation [110], social-environmental conflict management [111], and other areas. Here, we emphasize that, given that both PAR and PE arose in troubled social and political contexts of Latin America, they represent valuable sources of tools for place-based MSC in similar contexts of the Global South.

These contexts often include limited statehood, and PE and PAR are direct responses to these situations. Participatory methodologies for knowledge co-creation and collective action stemming from PE and PAR have bolstered networks of collaboration across non-government, rather than including government, actors. These networks of collaboration and political ties usually include academics, CSOs, and marginalized stakeholders [112-114]. Government and businesses do not commonly participate in these collaborative processes, in part because historically they have been regarded as accountable for the lack of social justice in Latin America [115-117]. In this context, PE and PAR in Latin American can be interpreted both as a result of a pervasive condition of limited statehood and as a producer of alternative forms of sustainability governance. As a result, these approaches offer a particularly useful conceptual framework and set of participatory methodologies to carry out MSC toward sustainability in contexts of the Global South and beyond.

\subsection{Limitations and Further Directions}

The limitations of our study highlight important priorities for further work. One priority is that, while the selected projects included stakeholders from different sectors of society, we did not evaluate the role of stakeholder composition on collaboration outcomes. Different profiles of stakeholders across collaborations can have a strong influence on the way collaborations are carried out [18], so this factor would be useful to examine. Also, our study did not include indicators of the success of individual projects in meeting their stated goals. As a result, our study in effect assumes that there should be no systematic tendency for more or less successful projects to involve differing relationships between challenges and strategies. Approaches for the evaluation of collaborations found in the trandisciplinary research literature $[118,119]$ would seem to offer useful potential for testing this expectation. The priorities for further work identified by our study thus seem readily addressed by available systems and approaches. 


\section{Conclusions}

Examination of place-based MSC experiences in Mexico highlighted strong agreement with studies focused on national and transnational partnerships and in contexts of the Global North, while at the same time, identifying significant obstacles largely overlooked in the previous literature. Finding that many challenges for place-based MSC identified here coincided with those of other social and political contexts and of high level partnerships suggests that there are rich opportunities to inform MSC practices and partnership designs across geographic contexts and partnership levels. Our results also highlighted the importance of examining perspectives from Latin America and other regions of the Global South $[44,120]$, given that this context is able to reveal obstacles largely overlooked in analyses based on other contexts [121]. These obstacles were associated with structural conditions in countries with areas of limited statehood, such as Mexico, conditions shared with many other countries of the Global South. These social and political conditions in which MSC occurs are critical for the success of place-based sustainability initiatives and lead to alternative forms of governance in which non-state actors are crucial. Because a large number of MSC initiatives operate under these circumstances in Mexico and across the Global South, critical analyses of MSC and environmental governance in these regions need to address these pervasive conditions explicitly. In areas of limited statehood, where the process of scaling-up place-based sustainability efforts faces structural obstacles, scaling-out networks of non-governmental stakeholders, such as the ones exemplified in this study, could be crucial for global sustainability. Further understanding these partnerships and the factors that obstruct or enable their success in the Global South is thus of paramount importance for the good governance and management of social-ecological systems globally.

Supplementary Materials: The following is available online at http://www.mdpi.com/2071-1050/10/9/3217/s1, Table S1: Characteristics of participating projects.

Author Contributions: Conceptualization, B.A.-O., J.A.R. and J.M.; Methodology, J.M., I.B. and A.L.; Formal Analysis, B.A.-O., J.A.R., J.M., I.B., G.A.-F., A.L.-F. and A.L.; Writing-Original Draft Preparation, B.A.-O. and J.A.R.; Writing-Review \& Editing, B.A.-O, J.A.R., J.M. and A.L.-F. All authors read and approved the final manuscript.

Funding: This research was funded by CONACyT, Mexico, through the Red de Socioecosistemas y Sustentabilidad, grant number 293862 (Redes Temáticas CONACyT).

Acknowledgments: We are deeply grateful to workshop participants, facilitators, and workshop hosts for sharing their inspiring experiences and perspective. We thank Tamara Ortiz for her support with workshop design, Mark Olson for comments and suggestions that greatly improved the manuscript, Gabriel Ramos-Fernández and Mario Siqueiros for their guidance with network analysis, and Patricia Balvanera for her support throughout the project. B.A.-O. and A.L.-F. acknowledge the support of CONACyT (grant number 2269 and 1734 respectively).

Conflicts of Interest: The authors declare no conflict of interest.

\section{References}

1. Rockström, J.; Steffen, W.; Noone, K.; Persson, Å.; Chapin, F.S., III; Lambin, E.F.; Lenton, T.M.; Scheffer, M.; Folke, C.; Schellnhuber, H.J.; et al. A safe operating space for humanity. Nature 2009, 461, 472-475. [CrossRef] [PubMed]

2. Barnosky, A.D.; Brown, J.H.; Daily, G.C.; Dirzo, R.; Ehrlich, A.H.; Ehrlich, P.R.; Eronen, J.T.; Fortelius, M.; Hadly, E.A.; Leopold, E.B.; et al. Introducing the scientific consensus on maintaining humanity's life support systems in the 21st century: Information for policy makers. Anthropocene Rev. 2014, 1, 78-109. [CrossRef]

3. Kates, R.W.; Clark, W.C.; Corell, R.; Hall, J.M.; Jaeger, C.C.; Lowe, I.; McCarthy, J.J.; Schellnhuber, H.J.; Bolin, B.; Dickson, N.M.; et al. Sustainability Science. Science 2001, 292, 641-642. [CrossRef] [PubMed]

4. Clark, W.C.; Dickson, N.M. Sustainability science: The emerging research program. Proc. Natl. Acad. Sci. USA 2003, 100, 8059-8061. [CrossRef] [PubMed]

5. Kates, R.W. What kind of a science is sustainability science? Proc. Natl. Acad. Sci. USA 2011, 108, 19449-19450. [CrossRef] [PubMed] 
6. Fadeeva, Z. Promise of sustainability collaboration-potential fulfilled? J. Clean. Prod. 2004, 13, 165-174. [CrossRef]

7. Meadowcroft, J. Democracy and accountability: The challenge for cross-sectoral partnerships. In Partnerships, Governance and Sustainable Development: Reflections on Theory and Practice; Glasbergen, P., Biermann, F., Mol, A.P.J., Eds.; Edward Elgar Publishing: Cheltenham, UK, 2007; pp. 197-213, ISBN 978-1-84720-866-8.

8. Bitzer, V.; Francken, M.; Glasbergen, P. Intersectoral partnerships for a sustainable coffee chain: Really addressing sustainability or just picking (coffee) cherries? Glob. Environ. Chang. 2008, 18, 271-284. [CrossRef]

9. Pattberg, P.; Widerberg, O. Transnational multistakeholder partnerships for sustainable development: Conditions for success. AMBIO 2016, 45, 42-51. [CrossRef] [PubMed]

10. Gallopín, G.C.; Funtowicz, S.; O'Connor, M.; Ravetz, J. Science for the twenty-first century: From social contract to the scientific core. Int. Soc. Sci. J. 2001, 53, 219-229. [CrossRef]

11. Baker, S. Sustainable Development; Routledge: London, UK, 2006, ISBN 978-0-415-28211-6.

12. Bäckstrand, K. Multi-stakeholder partnerships for sustainable development: Rethinking legitimacy, accountability and effectiveness. Environ. Policy 2006, 16, 290-306. [CrossRef]

13. Bonan, G.B. Forests and climate change: Forcings, feedbacks, and the climate benefits of forests. Science 2008, 320, 1444-1449. [CrossRef] [PubMed]

14. United Nations General Assembly Transforming our World: The 2030 Agenda for Sustainable Development. Available online: http:/ / www.refworld.org/docid/57b6e3e44.html (accessed on 3 May 2018).

15. Van Huijstee, M.M.; Francken, M.; Leroy, P. Partnerships for sustainable development: A review of current literature. Environ. Sci. 2007, 4, 75-89. [CrossRef]

16. Wood, D.J.; Gray, B. Toward a comprehensive theory of collaboration. J. Appl. Behav. Sci. 1991, 27, 139-162. [CrossRef]

17. Utting, P.; Zammit, A. United Nations-business partnerships: Good intentions and contradictory agendas. J. Bus. Ethics 2009, 90, 39-56. [CrossRef]

18. Gray, B.; Stites, J.P. Sustainability through Partnerships: Capitalizing on Collaboration; Network for Business Sustainability: London, ON, Canada, 2013.

19. Gray, B. Collaborating: Finding Common Ground for Multiparty Problems; JOSSEY BASS BUSINESS AND MANAGEMENT SERIES; Jossey-Bass: San Francisco, CA, USA, 1989, ISBN 978-1-55542-159-5.

20. Jahn, T. Transdisziplinäre Forschung: Integrative Forschungsprozesse verstehen und bewerten. In Transdisziplinäre Forschung. Integrative Forschungsprozesse Erstehen und bewerten; Schramm, E., Bergmann, M., Eds.; Campus Verlag: Frankfurt, Germany, 2008; pp. 21-37, ISBN 978-3-593-38846-5.

21. Lang, D.J.; Wiek, A.; Bergmann, M.; Stauffacher, M.; Martens, P.; Moll, P.; Swilling, M.; Thomas, C.J. Transdisciplinary research in sustainability science: Practice, principles, and challenges. Sustain. Sci. 2012, 7, 25-43. [CrossRef]

22. Scholz, R.W.; Steiner, G. The real type and ideal type of transdisciplinary processes: Part I-Theoretical foundations. Sustain. Sci. 2015, 10, 527-544. [CrossRef]

23. Klenk, N.L.; Meehan, K. Transdisciplinary sustainability research beyond engagement models: Toward adventures in relevance. Environ. Sci. Policy 2017, 78, 27-35. [CrossRef]

24. Vilsmaier, U.; Brandner, V.; Engbers, M. Research in-between: The constitutive role of cultural differences in transdisciplinarity. Transdiscipl. J. Eng. Sci. 2017, 8, 169-179. [CrossRef]

25. Ioppolo, G.; Cucurachi, S.; Salomone, R.; Saija, G.; Shi, L. Sustainable Local Development and Environmental Governance: A Strategic Planning Experience. Sustainability 2016, 8. [CrossRef]

26. Gray, B. The process of partnership construction: Anticipating obstacles and enhancing the likelihood of successful partnerships for sustainable development. In Partnerships, Governance and Sustainable Development: Reflections on Theory and Practice; Glasbergen, P., Biermann, F., Mol, A.P.J., Eds.; Edward Elgar Publishing: Cheltenham, UK, 2007; pp. 29-48, ISBN 978-1-84720-866-8.

27. Hirsch Hadorn, G.; Hoffmann-Riem, H.; Biber-Klemm, S.; Grossenbacher-Mansuy, W.; Joye, D.; Pohl, C.; Wiesmann, U.; Zemp, E. Handbook of Transdisciplinary Researc.; Springer: Dordrecht, The Netherlands, 2008, ISBN 978-1-4020-6699-3.

28. Angelstam, P.; Andersson, K.; Annerstedt, M.; Axelsson, R.; Elbakidze, M.; Garrido, P.; Grahn, P.; Jönsson, K.I.; Pedersen, S.; Schlyter, P.; et al. Solving problems in social-ecological systems: Definition, practice and barriers of transdisciplinary research. AMBIO 2013, 42, 254-265. [CrossRef] [PubMed] 
29. Pattberg, P.; Widerberg, O. Transnational Multi-Stakeholder Partnerships for Sustainable Development: Building Blocks for Success; Institute for Environmental Studies: Amsterdam, The Netherlands, 2014.

30. Bunders, J.F.G.; Bunders, A.E.; Zweekhorst, M.B.M. Challenges for transdisciplinary research. In Global Sustainability; Werlen, B., Ed.; Springer: Cham, Switzerland, 2015, ISBN 978-3-319-16477-9.

31. Brouwer, H.; Woodhill, J.; Hemmati, M.; Verhoosel, K.; van Vugt, S. The MSP Guide: How to Design and Facilitate Multi-Stakeholder Partnerships; Wageningen University and Research, CDI: Wageningen, The Netherlands, 2016, ISBN 978-1-78044-669-1.

32. Global Knowledge Partnership. Global Multi-Stakeholder Partnerships; Global Knowledge Partnership: Kuala Lumpur, Malaysia, 2003.

33. KPMG. Unlocking the Power of Partnership. A Framework for Effective Cross-Sector Collaboration to Advance the Global Goals for Sustainability Development; International Development Services, KPMG International: Amstelveen, The Netherlands, 2016.

34. Hardy, B.; Hudson, B.; Waddington, E. Assessing Strategic Partnership: The Partnership Assessment Tool; Office of the Deputy Prime Minister: London, UK, 2003.

35. Compassion Capital Fund National Resource Center; Publow, M. Partnerships: Frameworks for Working together. Available online: www.acf.hhs.gov/sites/default/files/ocs/partnerships.pdf (accessed on 2 May 2018).

36. Pattberg, P. Partnerships for sustainability: An analysis of transnational environmental regime. In Partnerships, Governance and Sustainable Development: Reflections on Theory and Practice; Glasbergen, P., Biermann, F., Mol, A.P.J., Eds.; Edward Elgar Publishing: Cheltenham, UK, 2007; pp. 173-193, ISBN 978-1-84720-866-8.

37. Beisheim, M.; Liese, A. Transnational Partnerships: Effectively Providing for Sustainable Development? Governance and Limited Statehood; Palgrave Macmillan: Basingstoke, UK, 2014, ISBN 978-1-137-35953-7.

38. Beisheim, M. Partnerships for Sustainable Development. Why and How Rio+20 must Improve the Framework for Multi-Stakeholder Partnerships; SWP Research Paper 2012/RP 03; SWP: Berlin, Germany, 2012.

39. Bellefontaine, T.; Wisener, R. The Evaluation of Place-Based Approaches. Questions for Further Research; Policy Horizons Canada: Toronto, ON, Canada, 2011; p. 33.

40. Carpenter, S.R.; Folke, C.; Norström, A.; Olsson, O.; Schultz, L.; Agarwal, B.; Balvanera, P.; Campbell, B.; Castilla, J.C.; Cramer, W. Program on ecosystem change and society: An international research strategy for integrated social-ecological systems. Curr. Opin. Environ. Sustain. 2012, 4, 134-138. [CrossRef]

41. Balvanera, P.; Calderón-Contreras, R.; Castro, A.J.; Felipe-Lucia, M.R.; Geijzendorffer, I.R.; Jacobs, S.; Martín-López, B.; Arbieu, U.; Speranza, C.I.; Locatelli, B.; et al. Interconnected place-based social-ecological research can inform global sustainability. Curr. Opin. Environ. Sustain. 2017, 29, 1-7. [CrossRef]

42. Alatorre-Frenk, G.; Merçon, J.; Rosell, J.A.; Bueno, I.; Ayala-Orozco, B.; Lobato Curiel, A. Para Construir lo Común Entre los Diferentes. Guía para la Colaboración Intersectorial Hacia la Sustentabilidad.; Red de Socioecosistemas y Sustentabilidad; Grupo de Estudios Ambientales, A.C.: Xalapa, México, 2016, ISBN 978-607-8445-47-9.

43. Maihold, G. Crimen y Violencia en América Latina: Retos de Gobernanza de Seguridad en Áreas de Presencia Limitada del Estado, 1st ed.; Fundaungo: San Salvador, El Salvador, 2015, ISBN 978-99923-29-67-2.

44. Nagendra, H. The global south is rich in sustainability lessons that students deserve to hear. Nature 2018, 557, 485-488. [CrossRef] [PubMed]

45. CONABIO. Capital Natural de México, Vol. I: Conocimiento Actual de la Biodiversidad; Comisión Nacional para el Conocimiento y Uso de la Biodiversidad: México DF, México, 2008, ISBN 978-607-7607-03-8.

46. INEGI. Censo de Población y Vivienda 2010; Instituto Nacional de Estadística, Geografía e Informática (INEGI): Aguascalientes, México, 2010.

47. Toledo, V.M.; Boege, E.; Barrera-Bassols, N. The biocultural heritage of Mexico: An overview. Landscape 2010, 3, 6-10.

48. Chant, S.H.; Mcllwaine, C. Geographies of Development in the 21st Century: An Introduction to the Global South; Edward Elgar Publishing: Cheltenham, UK, 2009, ISBN 978-1-84844-599-4.

49. Esguerra, A.; Helmerich, N.; Risse, T. Introduction: Sustainability politics and limited statehood. Contesting new modes of governance. In Sustainability Politics and Limited Statehood: Contesting the New Modes of Governance; Esguerra, A., Helmerich, N., Risse, T., Eds.; Governance and limited statehood series; Palgrave Macmillan: Basingstoke, UK, 2017; pp. 1-22, ISBN 978-3-319-39871-6.

50. Cox Aranibar, R. El Saber Local, Metodologías y Técnicas Participativas; NOGUB-COSUDE/CAF: La Paz, Bolivia, 1996.

51. CIMAS. Manual Metologías Participativas; Observatorio Internacional de Ciudadanía y Medio Ambiente Sostenible (CIMAS): Madrid, Spain, 2010. 
52. Kemmis, S.; McTaggart, R.; Nixon, R. The Action Research Planner. Doing Critical Participatory Action Research; Springer: London, UK, 2014, ISBN 978-981-4560-67-2.

53. Pereira, L.; Hichert, T.; Hamann, M.; Preiser, R.; Biggs, R. Using futures methods to create transformative spaces: Visions of a good Anthropocene in southern Africa. Ecol. Soc. 2018, 23. [CrossRef]

54. Behmel, S.; Damour, M.; Ludwig, R.; Rodriguez, M.J. Participative approach to elicit water quality monitoring needs from stakeholder groups-An application of integrated watershed management. J. Environ. Manag. 2018, 218, 540-554. [CrossRef] [PubMed]

55. Wals, A.E.J.; van der Hoeven, N.; Blanken, H. The Acoustics of Social Learning: Designing Learning Processes that Contribute to a More Sustainable World; Wageningen Academic Publishers: Wageningen, The Netherlands, 2009, ISBN 978-90-8832-009-5.

56. UNAM Código de Ética de la Universidad Nacional Autónoma de México. Available online: https: / consejo. unam.mx/static/documents / codigos/codigo-etica-unam.pdf (accessed on 3 November 2015).

57. Hernández, L. Antes de Empezar con Metodologías Participativas; Cuadernos CIMAS; Observatorio Internacional de Ciudadanía y Medio Ambiente Sostenible: Madrid, Spain, 2010.

58. Strauss, A.; Corbin, J. Basics of Qualitative Research Techniques and Procedures for Developing Grounded Theory, 2nd ed.; Sage: Thousand Oaks, CA, USA, 1998, ISBN 978-0-8039-5940-8.

59. Charmaz, K. Grounded theory: Objectivist and constructivist methods. In Handbook of Qualitative Research; Denzin, N.K., Lincoln, Y.S., Eds.; SAGE Publications: Thousand Oaks, CA, USA, 2000; pp. 509-535, ISBN 978-1-4833-4981-7.

60. Neuman, W. Social Research Methods: Qualitative and Quantitative Approaches, 3rd ed.; Allyn and Bacon: Boston, MA, USA, 2014, ISBN 978-0-205-19356-1.

61. Kluge, S. Empirically Grounded Construction of Types and Typologies in Qualitative Social Research. 2000. Forum Qualitative Social Research, 1. Available online: www.qualitative-research.net/index.php/fqs/ article/view/1124 (accessed on 4 March 2018).

62. Wasserman, S.; Faust, K. Social Network Analysis: Methods and Applications; Structural Analysis in the Social Sciences; Cambridge University Press: Cambridge, UK, 1994, ISBN 978-0-521-38707-1.

63. Borgatti, S.P.; Halgin, D.S. Analyzing affiliation networks. In The SAGE Handbook of Social Network Analysis; Scott, J., Carrington, P.J., Eds.; SAGE Publications: London, UK, 2011; pp. 417-433, ISBN 978-1-4739-7118-9.

64. Borgatti, S.; Everett, M.; Freeman, L. UCInet for Windows: Software for Social Network Analysis; Analytic Technologies: Harvard, MA, USA, 2002, ISBN 978-1-4614-6170-8.

65. Bastian, M.; Heymann, S.; Jacomy, M. Gephi: An open source software for exploring and manipulating networks. In Proceedings of the Third International ICWSM Conference, San Jose, CA, USA, 17-20 May 2009; Volume 8, pp. 361-362.

66. Cendejas, J.; Merino, L. Acción colectiva en la construcción social de la paz y la seguridad. La paz y la seguridad como bienes comunes. Cult. Represent. Soc. 2016, 10, 9-41.

67. Global Initiative. Organised Crime: A Cross-Cutting Threat to Sustainable Development; Global Initiative Against Transnational Organised Crime: Geneva, Switzerland, 2015.

68. Brower, L.P.; Taylor, O.R.; Williams, E.H.; Slayback, D.A.; Zubieta, R.R.; Ramirez, M.I. Decline of monarch butterflies overwintering in Mexico: Is the migratory phenomenon at risk? Insect Conserv. Divers. 2012, 5, 95-100. [CrossRef]

69. Altieri, M.A.; Masera, O. Sustainable rural development in Latin America: Building from the bottom-up. Ecol. Econ. 1993, 7, 93-121. [CrossRef]

70. Governance Without a State? Policies and Politics in Areas of Limited Statehood.; Risse, T. (Ed.) Columbia University Press: New York, NY, USA, 2011, ISBN 978-0-231-15121-4.

71. Risse, T. Governance in areas of limited statehood. In The Oxford Handbook of Governance; Levi-Faur, D., Ed.; Oxford Handbooks in Politics \& International Relations; Oxford University Press: Oxford, UK, 2012, ISBN 978-0-19-956053-0.

72. Börzel, T.A.; Risse, T.; Draude, A. Governance in areas of limited statehood: Conceptual clarifications and major contributions of the handbook. In The Oxford Handbook of Governance and Limited Statehood; Risse, T., Börzel, T.A., Draude, A., Eds.; Oxford University Press: Oxford, UK, 2018; pp. 3-28, ISBN 978-0-19-879720-3.

73. Beisheim, M.; Ellersiek, A.; Lorch, J. INGOs and multi-stakeholder partnerships. In The Oxford Handbook of Governance and Limited Statehood; Risse, T., Börzel, T.A., Draude, A., Eds.; Oxford University Press: Oxford, UK, 2018; pp. 211-230, ISBN 978-0-19-879720-3. 
74. Rhodes, R.A.W. The new governance: Governing without government. Polit. Stud. 1996, 44, $652-667$. [CrossRef]

75. Liese, A.; Beisheim, M. Transnational public-private partnerships and the provision of collective goods in developing countries. In Governance without a State? Policies and Politics in Areas of Limited Statehood; Governance and Limited Statehood; Risse, T., Ed.; Columbia University Press: New York, NY, USA, 2011; pp. 115-143, ISBN 978-0-231-15121-4.

76. Hamann, R.; Hoenke, J.; O’Riordan, T. Environmental and natural resource governance. In Oxford Handbook of Governance and Limited Statehood; Risse, T., Börzel, T.A., Draude, A., Eds.; Oxford University Press: Oxford, UK, 2018; pp. 498-519, ISBN 978-0-19-879720-3.

77. Del Conde, A. Illegal logging and its dynamics of violence within the P'urhépecha Plateau. Landsc. Violence 2015, 3, 6. [CrossRef]

78. Gray, B.; Purdy, J. Collaborating for Our Future: Multistakeholder Partnerships for Solving Complex Problems; Oxford University Press: Oxford, UK, 2018, ISBN 978-0-19-878284-1.

79. Pohl, C.; Rist, S.; Zimmermann, A.; Fry, P.; Gurung, G.S.; Schneider, F.; Speranza, C.I.; Kiteme, B.; Boillat, S.; Serrano, E.; et al. Researchers' roles in knowledge co-production: Experience from sustainability research in Kenya, Switzerland, Bolivia and Nepal. Sci. Public Policy 2010, 37, 267-281. [CrossRef]

80. Cundill, G.; Roux, D.; Parker, J. Nurturing communities of practice for transdisciplinary research. Ecol. Soc. 2015, 20. [CrossRef]

81. Schmidt, L.; Pröpper, M. Transdisciplinarity as a real-world challenge: A case study on a North-South collaboration. Sustain. Sci. 2017, 12, 365-379. [CrossRef]

82. Foley, R.W.; Wiek, A.; Kay, B.; Rushforth, R. Ideal and reality of multi-stakeholder collaboration on sustainability problems: A case study on a large-scale industrial contamination in Phoenix, Arizona. Sustain. Sci. 2017, 12, 123-136. [CrossRef]

83. Pretty, J.N. Participatory learning for sustainable agriculture. World Dev. 1995, 23, 1247-1263. [CrossRef]

84. Sirvent, M.T.; Rigal, L. La investigación acción participativa como un modo de hacer ciencia de lo social. Decisio 2014, 7-12. Available online: cdn.designa.mx/CREFAL/revistas-decisio/decisio38_saber2.pdf (accessed on 3 September 2018).

85. Schaefer-McDaniel, N.; Scott, A.N. Benefits and challenges of transdisciplinary research for urban health researchers. In Converging Disciplines; Springer: New York, NY, USA, 2011; pp. 13-22, ISBN 978-1-4419-6330-7.

86. Madsen, W.; O'Mullan, C. Power, participation and partnerships: Reflections on the co-creation of knowledge. Reflect. Pract. 2018, 19, 26-34. [CrossRef]

87. Quijano, A. Colonialidad del poder, eurocentrismo y América Latina. In La Colonialidad del Saber: Eurocentrismo y Ciencias Sociales. Perspectivas Latinoamericanas; Lander, E., Ed.; CLACSO: Buenos Aires, Argentina, 2000; pp. 201-246, ISBN 950-9231-51-7.

88. Briggs, J.; Sharp, J. Indigenous knowledges and development: A postcolonial caution. Third World $Q$. 2004, 25, 661-676. [CrossRef]

89. Santos, B.S. Una Epistemología del sur. La Reinvención del Conocimiento Y La Emancipación Social; CLACSO: Buenos Aires, Argentina, 2009, ISBN 978-607-03-0056-1.

90. Santos, B.S. Desconolonizar el Saber, Reinventar el Poder; Trilce: Montevideo, Uruguay, 2010, ISBN 978-9974-32-546-3.

91. Santos, B.S. Renovar la Teoría Crítica y Reinventar la Emancipación Social; CLACSO: Buenos Aires, Argentina, 2006, ISBN 987-1183-57-7.

92. Toledo, V.M. Indigenous peoples and biodiversity. Encycl. Biodivers. 2001, 3, 451-463.

93. Boege, E. El Patrimonio Biocultural de los Pueblos Indígenas de México; Instituto Nacional de Antropología e Historia: Mexico City, Mexico, 2008; Volume 33, ISBN 978-968-03-0385-4.

94. Springer, J.; Alcorn, J. Strengthening WWF Partnerships with Indigenous Peoples and Local Communities; WWF: Gland, Switzerland; Washington, DC, USA, 2007.

95. Berkes, F. Indigenous ways of knowing and the study of environmental change. J. R. Soc. N. Z. 2009, 39, 151-156. [CrossRef]

96. United Nations. State of the World's Indigenous Peoples; United Nations Publications: New York, NY, USA, 2009, ISBN 92-1-130283-8.

97. Fals-Borda, O. Ciencia Propia y Colonialismo Intelectual; C. Valencia Editores: Bogotá, Colombia, 1987, ISBN 958-9044-32-8.

98. Freire, P. Pedagogia do Oprimido; Paz e Terra: Rio de Janeiro, Brazil, 1970. 
99. Hurtado, C.N. Educación popular: Una mirada de conjunto. Decisio 2005, 3-14. Available online: http: //www.infodf.org.mx/escuela/curso_capacitadores/educacion_popular/decisio10_saber1.pdf (accessed on 3 September 2018).

100. Eizaguirre, M.; Zabala, N. Investigación-Acción-Participativa. In Diccionario de Acción Humanitaria y Cooperación al Desarrollo; Pérez de Armiño, K., Areizaga, M., Eds.; Icaria: Barcelona, Spain, 2006, ISBN 978-84-7426-502-9.

101. Martí, J. La investigación-acción participativa: Estructura y fases. In La Investigación Social Participativa; Villasante, T.R., Montañés, M., Martí, J., Eds.; El Viejo Topo: Madrid, Spain, 2000; pp. 73-117, ISBN 978-84-95776-45-7.

102. Méndez, E.V.; Caswell, M.; Gliessman, R.S.; Cohen, R. Integrating Agroecology and Participatory Action Research (PAR): Lessons from Central America. Sustainability 2017, 9. [CrossRef]

103. Villasante, T.R. La Investigación Social Participativa. Construyendo Ciudadanía; El Viejo Topo: Madrid, Spain, 2002, ISBN 978-84-95776-45-7.

104. Villasante, T.R. La socio-praxis: Un acoplamiento de metodologías implicativas. In Metodologías de la Investigación Social; Canales, M., Ed.; Lom Ediciones: Santiago de Chile, Chile, 2006; pp. 379-406, ISBN 978-956-282-840-6.

105. Martinez-Alier, J.; Temper, L.; Del Bene, D.; Scheidel, A. Is there a global environmental justice movement? J. Peasant Stud. 2016, 43, 731-755. [CrossRef]

106. Thiollent, M.; Silva, G. de O. The Use of Action Research in the Management of Environmental Problems. Rev. Eletr. Comun. Inf. E Inov. Em Saúde 2007, 1, 91-98.

107. Ferraz de Toledo, R.; Jacobi, P.R. Pesquisa-ação e educação: Compartilhando princípios na construção de conhecimentos e no fortalecimento comunitário para o enfrentamento de problemas. Educ. Soc. 2013, 34, 155-173. [CrossRef]

108. Jordan, S. From a methodology of the margins to neoliberal appropiation and beyond: The lineages of participatory action research. In Education, Participatory Action Research, and Global Change; Kapoor, D., Jordan, S., Eds.; Palmgrave Macmillan: New York, NY, USA, 2009; pp. 15-28, ISBN 978-0-230-10064-0.

109. Wilmsen, C.; Elmendorf, W.F.; Fisher, L.; Ross, J.; Sarathy, B.; Wells, G. Partnerships for Empowerment: Participatory Research for Community-Based Natural Resource Management; Routledge: Abingdon, UK, 2012, ISBN 978-1-136-56007-1.

110. Mapfumo, P.; Adjei-Nsiah, S.; Mtambanengwe, F.; Chikowo, R.; Giller, K.E. Participatory action research (PAR) as an entry point for supporting climate change adaptation by smallholder farmers in Africa. Environ. Dev. 2013, 5, 6-22. [CrossRef]

111. Castro, A.P.; Nielsen, E. Natural Resource Conflict Management Case Studies: An Analysis of Power, Participation and Protected Areas; Food and Agriculture Organization of the United Nations: Rome, Italy, 2003.

112. Leyva Solano, X.; Burguete, A.; Speed, S. Gobernar (en) la Diversidad: Experiencias Indígenas Desde América Latina. Hacia la Investigación de Co-Labor; FLACSO: México DF, México, 2008, ISBN 978-968-496-671-0.

113. Escobar, A. Territorios de Diferencia: Lugar, Movimientos, Vidas, Redes; Envión: Popayán, Colombia, 2010, ISBN 978-958-99438-3-0.

114. Hale, C.R.; Stephen, L. Otros Saberes: Collaborative Research on Indigenous and Afrodescendant Cultural Politics; School for Advanced Research Press: Houston, TX, USA, 2013, ISBN 1-934691-55-0.

115. Olivé, E. Interculturalismo y Justicia Social; Universidad Nacional Autónoma de México: México DF, México, 2004, ISBN 8626000000539.

116. Alimonda, H.; Toro Pérez, C.; Martín, F. Ecología Política Latinoamericana. Pensamiento Crítico, Diferencia Latinoamericana y Rearticulación Epistémica; CLACSO: Buenos Aires, Argentina, 2017.

117. Calderón Gutiérrez, F. Los límites de la Democracia; CLACSO: Buenos Aires, Argentina, 2017, ISBN 978-987-722-300-2.

118. Walter, A.I.; Helgenberger, S.; Wiek, A.; Scholz, R.W. Measuring societal effects of transdisciplinary research projects: Design and application of an evaluation method. Eval. Progr. Plann. 2007, 30, 325-338. [CrossRef] [PubMed]

119. Wiek, A.; Talwar, S.; O'Shea, M.; Robinson, J. Toward a methodological scheme for capturing societal effects of participatory sustainability research. Res. Eval. 2014, 23, 117-132. [CrossRef] 
120. Chilisa, B. Decolonising transdisciplinary research approaches: An African perspective for enhancing knowledge integration in sustainability science. Sustain. Sci. 2017, 12, 813-827. [CrossRef]

121. Meehan, K.; Klenk, N.L.; Mendez, F. The Geopolitics of Climate Knowledge Mobilization: Transdisciplinary Research at the Science-Policy Interface (s) in the Americas. Sci. Technol. Hum. Values 2017, 0162243917745601. [CrossRef] article distributed under the terms and conditions of the Creative Commons Attribution (CC BY) license (http:/ / creativecommons.org/licenses/by/4.0/). 